\title{
Pella glooscapi, a new rove beetle, and new records of aleocharines from Nova Scotia, Canada (Coleoptera, Staphylinidae)
}

\author{
Jan Klimaszewskil,†, Derek Lynch ${ }^{2, \ddagger}$, Christopher G. Majka ${ }^{3, \S}$, \\ Justin Renkemaa ${ }^{4,1}$, Karine Savard ${ }^{1, \pi}$, Peter Hlaváč ${ }^{5, \#}$
}

I Natural Resources Canada, Canadian Forest Service, Laurentian Forestry Centre, 1055 du PEPS, P.O. Box 10380, Stn. Sainte-Foy, Quebec, Quebec, Canada G1V 4 C7 2 Nova Scotia Agricultural College, Department of Plant and Animal Sciences, 50 Pictou Rd., Truro, Nova Scotia, Canada B2N $5 E 33$ clo Nova Scotia Museum, 1747 Summer Street, Halifax, Nova Scotia, Canada B3H 3 A6 4 Dalhousie University, Department of Biology, 1355 Oxford St., Halifax, Nova Scotia, Canada B3H $4 J 15$ Na doline 14, SK-040 Košice, Slovakia

† urn:lsid:zoobank.org:author:75880C14-430B-45F6-8B6D-840428F3FF37

† urn:lsid:zoobank.org:author:B8A1C258-3B78-42BF-AD46-24093DFE1300

§ urn:lsid:zoobank.org:author:A4C6781A-404E-44A7-9743-73B2F430E630

| urn:lsid:zoobank.org:author:722EB956-5F45-41D1-B092-541167CAD6F1

I urn:lsid:zoobank.org:author:716D03A0-DF55-4A60-AA54-DF4C0F4A8E7E

\# urn:lsid:zoobank.org:author:3FA8D0BB-B332-4173-8239-9AB9F6DC9150

Corresponding author: Jan Klimaszewski (jan.klimaszewski@nrcan-rncan.gc.ca)

Academic editor: Volker Assing | Received 6 February 2009 | Accepted 7 May 2009 | Published 28 September 2009 urn:lsid:zoobank.org:pub:363F741F-A255-4D47-B554-759CCD1C70DA

Citation: Klimaszewski J, Lynch D, Majka CG, Renkema J, Savard K, Hlaváč P (2009) Pella glooscapi, a new rove beetle, and new records of aleocharines from Nova Scotia, Canada (Coleoptera, Staphylinidae). In: Majka CG, Klimaszewski J (Eds) Biodiversity, Biosystematics, and Ecology of Canadian Coleoptera II. ZooKeys 22: 35-44. doi: 10.3897/zookeys. 45.95

\begin{abstract}
A new aleocharine rove beetle, Pella glooscapi Klimaszewski and Majka sp. n., from Nova Scotia, Canada, is described and illustrated. Data on bionomics and distribution are provided. A short diagnosis, description, colour body image, and black and white genital images are also provided. It appears to be closely related to P. criddlei (Casey). Pella loricata (Casey), Zyras obliquus (Casey), and Dalotia coriaria (Kraatz) are newly recorded from Nova Scotia, and for Atlantic Canada as a whole.
\end{abstract}

Copyright Her Majesty the Queen in Right of Canada. This is an open access article distributed under the terms of the Creative Commons Attribution License, which permits unrestricted use, distribution, and reproduction in any medium, provided the original author and source are credited. 


\section{Keywords}

Staphylinidae, Aleocharinae, Canada, Coleoptera, Nova Scotia, Pella, Zyras, Dalotia, taxonomy

\section{Introduction}

Pella Stephens (1835) is a myrmecophilous genus belonging to the aleocharine tribe Lomechusini Fleming (Coleoptera, Staphylinidae). It is represented by 48 Palaearctic species (including China and northern states of India) and 10 Nearctic species, of which eight, including the one described herein, occur in Canada (Klimaszewski et al. 2005; Maruyama 2006; Hlaváč, pers. comm.). Species of this genus are mainly associated with the ant species of the genus Lasius (subgenus Cautolasius, Dendrolasius, Chthonolasius, and Lasius), and occasionally with Formica, Liometopum, and Tapinoma (Klimaszewski et al. 2005).

The main goal of this contribution is to describe and document a new species, Pella glooscapi Klimaszewski \& Majka, sp. n., recently discovered in Nova Scotia, and to publish new Nova Scotia provincial distribution records for Pella loricata (Casey 1894), Zyras obliquus (Casey, 1894), and Dalotia coriaria (Kraatz, 1856), an adventive Palaearctic species.

\section{Material and methods}

Seven adults of Pella glooscapi Klimaszewski \& Majka, sp. n., and three P. loricata were found in a highbush blueberry (Vaccinium corymbosum L., Ericaceae) field in Nova Scotia, Canada. All specimens were dissected. The genital structures were dehydrated in absolute alcohol and mounted in Canada balsam on celluloid microslides and pinned with the specimens from which they originated. The photographs of the entire body and the genital structures were taken using an image processing system (Nikon SMZ 1500 stereoscopic microscope; Nikon Digital Camera DXM 1200F; and Adobe Photoshop software).

Terminology mainly follows that used by Klimaszewski et al. (2005) and Maruyama (2006). The ventral part of the median lobe of the aedeagus is considered to be the part of the bulbus containing the foramen mediale, the entrance of the ductus ejaculatorius, and the adjacent venter of the tubus; the opposite side is referred to as the dorsal part.

\section{Depository abbreviations:}

CGMC Christopher G. Majka Collection, Halifax, Nova Scotia, Canada

LFC Natural Resources Canada, Canadian Forest Service, Laurentian Forestry Centre, Insectarium R. Martineau, Quebec City, Quebec, Canada

NSMC Nova Scotia Museum, Halifax, Nova Scotia, Canada 


\section{Tribe Lomechusini Fleming, 1821}

(For literature review and diagnosis, see Maruyama (2006)).

\section{Genus Pella Stephens, 1835}

(For literature review, synonymy, description, diagnosis, and illustrations, see Klimaszewski et al. (2005) and Maruyama (2006)).

\section{Pella glooscapi Klimaszewski \& Majka, sp. n.} urn:lsid:zoobank.org:act:CC905F4C-29C9-4D1C-A761-E49D84E006BE Figs $1-10$

Holotype. Male. CANADA, Nova Scotia, Upper Rawdon, Hants Co., NS, 28.VIII.2008, J. Renkema, highbush blueberry field R2T1C (LFC). Paratypes: CANADA, Nova Scotia, Upper Rawdon, Hants Co., J. Renkema, highbush blueberry field: R2T1C, (LFC) 1 female; R2T1C, 26.VIII.2008 (CGMC) 1 male; R3T5A, 14.VIII.2008 (CGMC) 1 male; R2T1C, 9.IX.2008 (CGMC) 1 male; 12.IX.2008 (CGMC) 1 male; R2T1C, 25.VI.2008 (CGMC) 1 male.

Etymology. The name of this new species is derived from the name Glooscap, a mythical creator and cultural hero of the Wabanaki native peoples (the Abenaki, Mi'kmaq, Penobscot, Passamaquoddy, and Maliseet). According to the Mi'kmaq legend, when Glooscap slept, Nova Scotia was his bed and Prince Edward Island his pillow. Glooscap was the source of early environmental myths, teaching hunters that those who kill too much would destroy the world he created. According to legend, Glooscap inhabited the region where Pella glooscapi has been found. He supposedly created the neighbouring Five Islands in the Bay of Fundy by throwing stones at a giant beaver that built a dam to flood his medicine garden in Advocate. Accordingly we name this new species in honour of the rich mythology of the people of the Wabanaki Confederacy.

Diagnosis. Pella glooscapi is similar in general appearance to P. loricata but may be easily distinguished by the uniformly black body (except for tarsi and basal parts of antennae), more robust antennae (Figs. 1,2), and differently shaped median lobe of aedeagus with broad and sinuate tubus in lateral view (Fig. 4) and the shape of spermatheca (Fig. 8). The closest known relative of this species would appear to be P. criddlei (Casey 1911), from which it may be distinguished by the black body and differently shaped male genitalia (Figs. 3-5). The latter two species have an almost identical spermatheca. This and other Pella species may readily be distinguished from members of the genus Drusilla by their lack of a distinct neck, and from the majority of Myrmoecia species by lacking abdominal trichomes and the characteristic tuberosities on the $2^{\text {nd }}$ and $3^{\text {rd }}$ visible abdominal tergites (Klimaszewski et al. 2005).

Description. Body length $3.4-3.8 \mathrm{~mm}$, subparallel, black with basal parts of antennae and tarsi reddish brown, integument glossy, forebody with distinct isodiametric microsculpture, punctation fine, pubescence yellow-brown, short and sparse, abdo- 


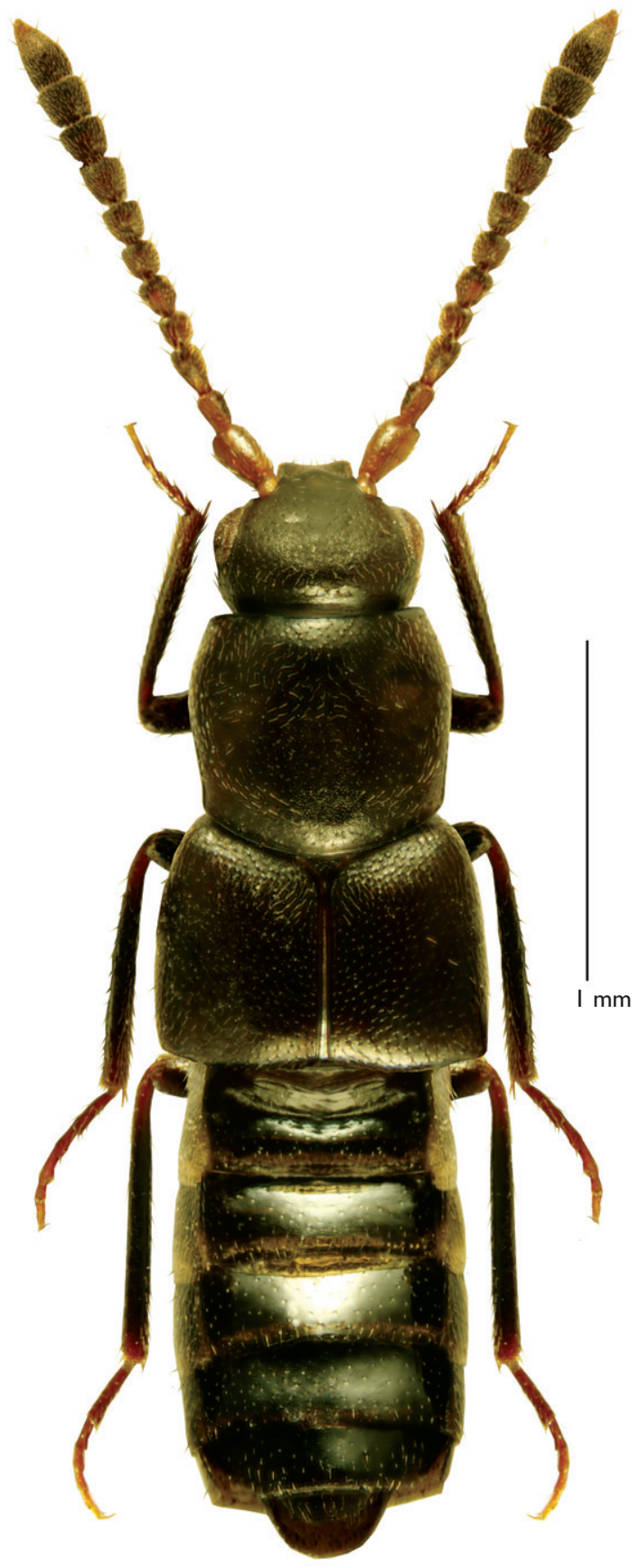

Figure I. Pella glooscapi sp. n., in dorsal view. 


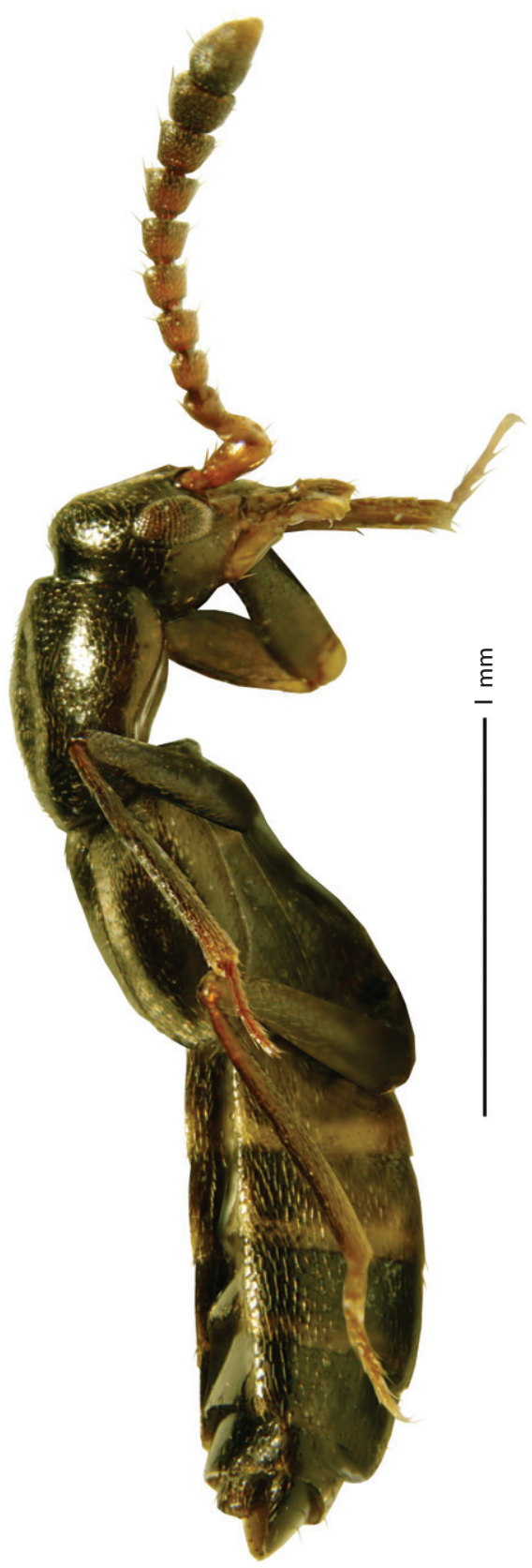

Figure 2. Pella glooscapi sp. n., in lateral view. 


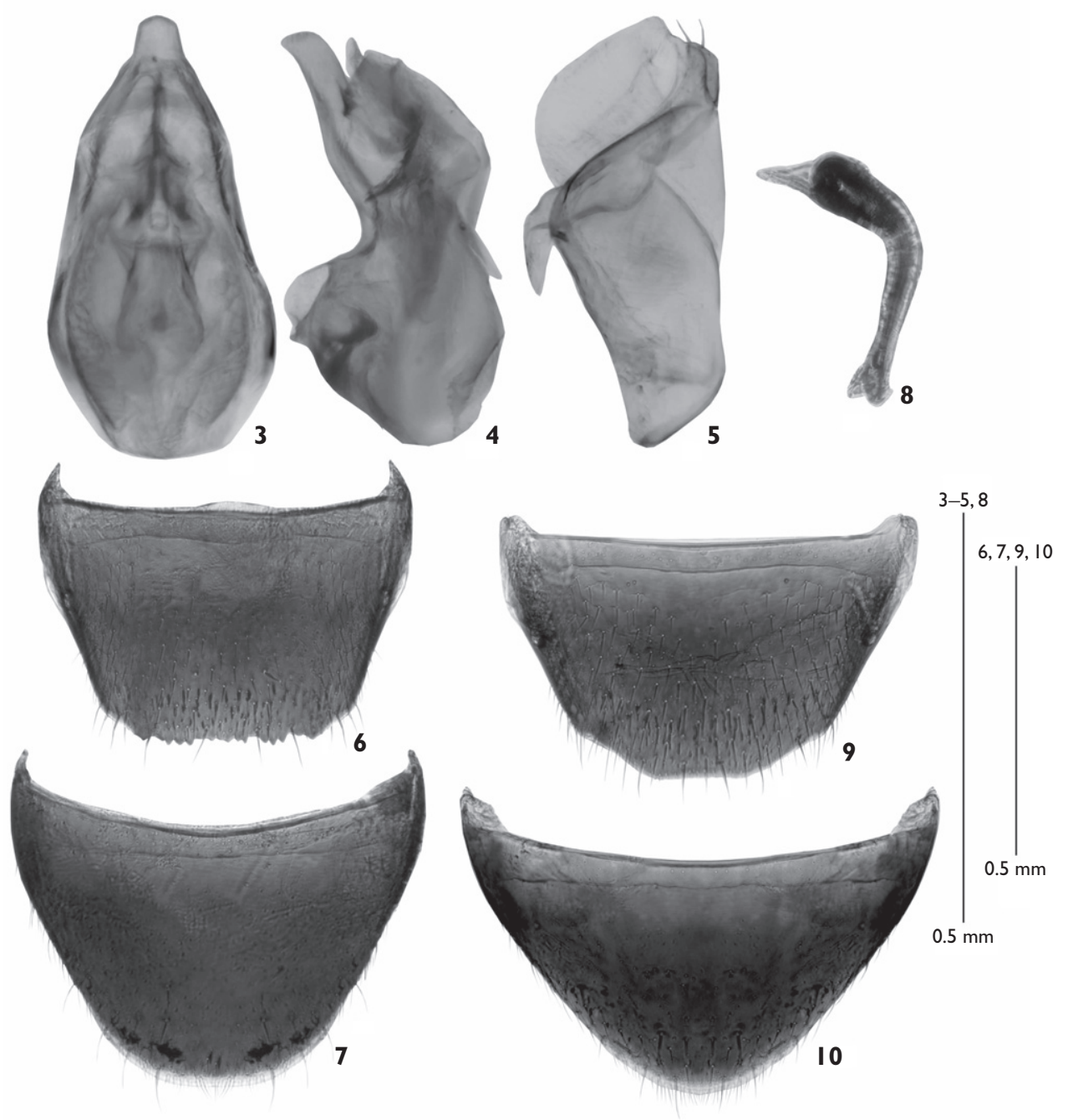

Figures 3-10. Genital structures of Pella glooscapi sp. n.: 3-10 (male): 3, median lobe of aedeagus in dorsal view, and $\mathbf{4}$, in lateral view; $\mathbf{5}$, paramere; $\mathbf{6}$, tergite $8 ; \mathbf{7}$, sternite 8; 8-10 (female): $\mathbf{8}$, spermatheca; $\mathbf{9}$, tergite 8 ; and $\mathbf{1 0}$, sternite 8 .

men with central areas of tergal discs glabrous (Fig. 1); antennae robust (Figs. 1, 2), reddish-brown basally and black apically, about as long as head, pronotum, and elytra combined, basal article large and swollen, as long as $2^{\text {nd }}$ and $3^{\text {rd }}$ combined, $2^{\text {nd }}$ article about $2 / 3$ as long as $3^{\text {rd }}, 3^{\text {rd }}$ article about $2 / 3$ of the $1^{\text {st }}, 4^{\text {th }}-7^{\text {th }}$ almost as long as wide, $7^{\text {th }}-10^{\text {th }}$ slightly wider than long, $11^{\text {th }}$ slightly longer than penultimate (Figs. 1, 2); maxillary palpi 4-articled, last article needle-shaped and about 1/4 the length of the penultimate article; head elongate, broadest at eye level, strongly constricted basally, 
pubescence directed obliquely inwards on centre of the disc (Fig. 1); pronotum trapezoidal in shape (Fig. 1), longer than elytra, widest in apical third, strongly convex with centro-basal depression, pubescence directed posterad and forming ring around the depression, hypomeron very strong and almost as long as pronotum laterally (Fig. 2); elytra (Fig. 1) slightly broadened posteriorly, pubescence directed straight or obliquely posterad, at base obliquely laterad; abdomen with three first visible basal tergites bearing deep longitudinal depressions, sometimes posterior edges of tergites lighter in colour, lateral edges of sternites slightly produced over sternites. Male. Tergite 8 transverse, space between antecostal suture and base of tergite narrow, antecostal suture approximately straight, apical margin truncate and with irregular small dents (Fig. 6). Sternite 8 transverse, space between antecostal suture and base of sternite narrow, antecostal suture approximately straight, apical margin broadly rounded, macrosetae small (Fig. 7); median lobe of aedeagus broadly oval in dorsal view (Fig. 3), bulbus gradually merging with tubus and tapering apically, apex broad and rounded (Fig. 3); tubus sinuate laterally and broad, apex slightly produced ventrally (Fig. 4); internal sac structures and paramere as illustrated (Figs. 3-5). Female. Tergite 8 transverse, space between antecostal suture and base of tergite narrow, antecostal suture approximately straight, apical margin truncate and smooth (Fig. 9). Sternite 8 transverse, space between antecostal suture and base of sternite narrow, antecostal suture approximately straight, apical margin broadly rounded, macrosetae small (Fig. 10). Spermatheca Lshaped, capsule with sharply produced apical projection (Fig. 8).

Bionomics. Adults were collected in June, July, August, and September in a highbush blueberry field. The area is one of mixed highbush and lowbush blueberry fields and re-growing old fields, with neighbouring mixed forests and a beaver pond.

Distribution. Known only from Nova Scotia, Canada.

Comments. In Klimaszewski et al. (2005), Pella glooscapi keys out to couplet 12, which is modified as follows to include the new species:

12 Body bicoloured, yellowish-brown (Fig. 11 in Klimaszewski et al. 2005); genitalia as illustrated (Figs. 41-43 in Klimaszewski et al. 2005)

P. fauveli Sharp

- $\quad$ Body approximately uniformly brown or black …….................................12

12A Pronotum slightly to strongly transverse ..............................................13

- $\quad$ Pronotum strongly elongate, genital structures as illustrated (Figs. 1, 3-10) ..

Pella glooscapi Klimaszewski \& Majka, sp. n.

\section{Pella loricata (Casey, 1894)}

(For description and illustrations, see Klimaszewski et al. (2005)).

CANADA, Nova Scotia, Upper Rawdon, Hants Co., 16.VII.2008, J. Renkema, highbush blueberry field R1T6E (LFC) 1 male; R1T6H, 18.VII.2008 (CGMC) 1 female; R1T6H, 19.VII.2008 (CGMC) 1 female. 
Pella loricata was described by Casey (1894) from Ohio, USA. Klimaszewski et al. (2005) reported this species for the first time in Canada from Ontario. We herein provide the first record of $P$. loricata from Nova Scotia.

\section{Zyras (s. str.) obliquus (Casey, 1894)}

(For description and illustrations, see Klimaszewski et al. (2005)).

CANADA, Nova Scotia, Bridgewater, 1-16.VII.1965, B. Wright, pitfall trap under red oak (NSMC) 1 male.

Zyras obliquus is a widely distributed North American species recorded by Klimaszewski et al. (2005) from British Columbia, Alberta, Manitoba, Ontario, and Québec in Canada and from Michigan, Missouri, New Hampshire, New York, and Oregon. We herein provide the first record of Z. obliquus from Nova Scotia.

\section{Dalotia coriaria (Kraatz, 1856)}

(For diagnosis, illustrations and literature reviews, see Klimaszewski et al. (2007) and Gouix and Klimaszewski (2007)).

CANADA, Nova Scotia, Upper Rawdon, Hants Co., 14.VIII.2008, highbush blueberry field R2T3A, J. Renkema (CGMC) 1 male.

Dalotia coriaria is a cosmopolitan species that is adventive in many parts of the world including Europe, east Africa, Madagascar, New Zealand, Galapagos Islands (Benick and Lohse 1974; Pace 1999; Sivasubramaniam et al. 1997; Klimaszewski and Peck 1998), and North America (Klimaszewski et al. 2007). In Canada it has previously been recorded from Ontario and Alberta (Klimaszewski et al. 2007; Gouix and Klimaszewski 2007), and in the United States from California, Florida, Louisiana, Massachusetts, New Jersey, and New York (Moore and Legner 1975; Muona 1984; Frank 1980; Gusarov 2003). This species is herein newly recorded from Nova Scotia.

\section{Discussion}

The addition of Pella glooscapi, P. loricata, and $Z$. obliquus to the faunal list of Nova Scotia substantially increases our knowledge about the myrmecophilous aleocharines found in the region. Previously Majka and Klimaszewski (2008a) reported Drusilla canaliculata (Fabricius, 1787) from Nova Scotia and Majka and Klimaszewski (2008b) added Xenodusa reflexa (Walker) to the provincial list. Drusilla canaliculata is a suspected myrmycophage while $X$. reflexa is a myrmecophile; both are members of the Lomechusini. The status of $D$. canaliculata as a myrmecophage remains to be verified. This species is frequently found in riparian habitats (R. Webster, pers. com.). Clearly, the myrmecophilous fauna of Nova Scotia is much more diverse than previously known. 
Further research on the distribution, bionomics, and associated ant species of these species in the region is warranted.

Dalotia coriaria is the $88^{\text {th }}$ species of adventive staphylinid to be recorded in the Maritime Provinces, and the $77^{\text {th }}$ from Nova Scotia (Majka and Klimaszewski 2008b). The very high proportion of adventive species found in this region is apparent when one considers that of the 38 adventive aleocharines recorded by Gouix and Klimaszewski (2007) in Canada and Alaska, 31 (82\%) are found in the Maritime Provinces. Majka and Klimaszewski (2008a) have discussed the different modes of introduction and dispersal of adventive Staphylinidae in the region.

\section{Acknowledgements}

We thank Pamela Cheers (LFC) for editing the first draft of this manuscript and D. Paquet for formatting it. Reginald Webster revised the first draft of this manuscript and provided very useful comments. Many thanks to Sandy Walde (Dalhousie University) and Andrew Hebda (Nova Scotia Museum) for their assistance.

\section{References}

Benick G, Lohse, GA (1974) Tribus: Callicerini (Atheta). In: Freude, H, Harde, KW, Lohse GA (Eds) Die Käfer Mitteleuropas. Band 5: Staphylinidae II (Hypocyphtinae und Aleocharinae) Pselaphidae. Goecke \& Evers Verlag, Krefeld, 72-221.

Casey TL (1894) Coleopterological notices. 5. Annals of the New York Academy of Sciences 7: 281-606.

Casey TL (1911) New American species of Aleocharinae and Myllaeninae. Memoirs on the Coleoptera. 2, The New Era Printing Co., Lancaster, Pennsylvania, 183 pp.

Fleming J (1821) Insects. In: Supplement to the fourth, fifth and sixth editions of the Encyclopaedia Britannica, vol. 5. A. Constable, Edinburgh, 41-56, pl. 85.

Frank JH (1980) Atheta coriaria (Kraatz) (Aleocharinae) and Sunius confluentus (Say) (Paederinae) in Florida (Coleoptera, Staphylinidae). The Coleopterists Bulletin 34: 388.

Gouix N, Klimaszewski J (2007) Catalogue of Aleocharine Rove Beetles of Canada and Alaska (Coleoptera, Staphylinidae, Aleocharinae). Pensoft Publishers, Sofia-Moscow, 166 pp.

Gusarov VI (2003) Revision of some types of North American aleocharines (Coleoptera: Staphylinidae: Aleocharinae), with synonymic notes. Zootaxa 353: 1-134.

Klimaszewski J, Peck SB (1998) A review of aleocharine rove beetles from the Galapagos Islands, Ecuador (Coleoptera: Staphylinidae, Aleocharinae). Revue suisse de Zoologie 105: 221-260.

Klimaszewski J, Pelletier G, Maruyama M, and Hlavač P (2005) Canadian species of the Zyras group of genera and review of the types from America north of Mexico. Revue suisse de Zoologie 112: 703-733. 
Klimaszewski J, Assing V, Majka CG, Pelletier G, Webster RP, Langor D (2007) Records of adventive aleocharine beetles (Coleoptera: Staphylinidae: Aleocharinae) found in Canada. The Canadian Entomologist 139: 54-79.

Kraatz G (1856) Staphylinii. Naturgeschichte der Insecten Deutschlands. Vol 2. Nicolai, Berlin: $1-376$.

Majka CG, Klimaszewski J (2008a) Introduced Staphylinidae (Coleoptera) in the Maritime Provinces of Canada. The Canadian Entomologist 140: 48-72.

Majka CG, Klimaszewski J (2008b) Adventive Staphylinidae (Coleoptera) of the Maritime Provinces of Canada: further contributions. In: Majka CG, Klimaszewski J (Eds) Biodiversity, Biosystematics, and Ecology of Canadian Coleoptera. ZooKeys 2: 151-174.

Maruyama M (2006) Revision of the Palaearctic species of the myrmecophilous genus Pella (Coleoptera, Staphylinidae, Aleocharinae). National Science Museum 32, Tokyo, 207 pp.

Moore I, Legner EF (1975) A catalogue of the Staphylinidae of America north of Mexico (Coleoptera). University of California Division of Agricultural Sciences, Special Publication 3015: 1-514.

Muona J (1984) Review of Palaearctic Aleocharinae also occurring in North America (Coleoptera: Staphylinidae). Entomologica Scandinavica 15: 227-231.

Pace R (1999) Insectes Coléoptères Staphylinidae Aleocharinae. Faune de Madagascar, Paris 89: 1-261.

Sivasubramaniam W, Wratten SD, Klimaszewski J (1997) Species composition, abundance, and activity of predatory arthropods in carrot fields, Canterbury, New Zealand. New Zealand Journal of Zoology 24: 205-212.

Stephens JF (1835) Illustrations of British Entomology; or a synopsis of indigenous insects: containing their generic and specific distinctions, with an account of their metamorphoses, times of appearances, localities, food, and economy, as far as practical. Mandibulata 5: 369-448. 